\title{
Investigating the Ameliorative Potential of the Aloe barbadensis Aqueous Fraction on Oxidative Stress Markers and Biochemical Parameters in Cadmium-Intoxicated Rabbits
}

\author{
Naqi Hussain"*, Muhammad Nawaz Chaudhary, Aftab Ahmed Anjum², \\ Naeem Abbas ${ }^{3}$, Muhammad Naeem Khan ${ }^{4}$, Syed Maaz Nadeem ${ }^{5}$ \\ ${ }^{1}$ College of Earth and Environmental Sciences, University of the Punjab, Lahore \\ ${ }^{2}$ Department of Microbiology, University of Veterinary and Animal Sciences, Lahore \\ ${ }^{3}$ Centre of Environmental Protection Studies, Pakistan Council of Scientific and Industrial Research, Lahore \\ ${ }^{4}$ Applied Chemistry Research Centre, Pakistan Council of Scientific and Industrial Research, Lahore \\ ${ }^{5}$ Department of Pathology, University of Veterinary and Animal Sciences, Lahore
}

Received: 16 June 2016

Accepted: 15 July 2016

\begin{abstract}
This study was conducted to evaluate the possible protective effects of the flavonoid-rich fraction of Aloe barbadensis leaf skin on cadmium (Cd)-induced toxicity in male albino rabbits. Cadmium is a notable environmental pollutant due to its wider range of toxic manifestations. The aqueous fraction of aloe extract (AAF) showed higher phenolics, flavonoids, and antioxidant capacity among other fractions, suggesting its rationale use in this study. Twenty-four rabbits were randomly divided into four groups, including the control group (receiving only vehicle), the Cd group (receiving Cd, $5.1 \mathrm{mg} / \mathrm{kg} / \mathrm{day}$ ), the AAF groups (receiving AAF, $200 \mathrm{mg} / \mathrm{Kg} / \mathrm{day}$ ), and the $\mathrm{Cd}+\mathrm{AAF}$ group (receiving the same concentrations as the $\mathrm{Cd}$ and AAF groups). Oral treatment over a period of 40 days significantly increased $(\mathrm{p}<0.05)$ biochemical marker enzymes, including transaminases (AST, ALT), alkaline phosphatase, $\gamma$-glutamyl transferase, creatinine, and urea, while total bilirubin $(\mathrm{Tb})$ and albumin were decreased on days 10, 20, 30, and 40 in the $\mathrm{Cd}$ group as compared to control. A significant decrease $(\mathrm{p}<0.05)$ in enzyme levels and increases in $\mathrm{Tb}$ and albumin for $\mathrm{Cd}+\mathrm{AAF}$ were observed as compared to $\mathrm{Cd}$-treated rabbits. Contents of superoxide dismutase, catalase, and vitamins $\mathrm{C}$ and $\mathrm{E}$ in liver and kidney tissues were significantly increased $(\mathrm{p}<0.05)$, while cadmium content was significantly decreased $(\mathrm{p}<0.05)$ for $\mathrm{Cd}+\mathrm{AAF}$ rabbits as compared to Cd-intoxicated rabbits. Values of all the parameters in only the AAF group were near to control. The histopathological studies for liver and kidney have also supported the $\mathrm{Cd}+\mathrm{AAF}$ group markedly reducing the toxicity of $\mathrm{Cd}$ in both tissues to near normal. Thus, the results suggest that the flavonoid-rich fraction of AAF may
\end{abstract}

*e-mail: syed_naqi@hotmail.com 
act as a natural protective agent against $\mathrm{Cd}$ toxicity via suppressing oxidative stress due to higher antioxidant activity.

Keywords: cadmium toxicity, aqueous fraction, antioxidant capacity, transaminases, histopathological studies

\section{Introduction}

It is evident that increasing anthropogenic activities modified the cycle of heavy metals and metalloids globally, including toxic elements like cadmium. Thus an ample opportunity for exposure to cadmium is possible in and outside the workplace [1-2]. Concentrations of $\mathrm{Cd}$ in the surrounding environment are increasing due to its diverse sources and prolonged biological half-life of 1030 years. It is nonessential and known to be toxic even at low concentrations [3-4]. Both acute and chronic exposure to $\mathrm{Cd}$ results in damage to plants, animals, and humans, including injury to the liver, lungs, testes, renal dysfunction, anemia, osteoporosis, DNA damage, neurodegenerative diseases, intestinal damage, and immunosuppressive and pro-inflammatory effects mainly due to oxidative stress [4-9]. Many approaches have been employed to reduce cadmium toxicity, including antioxidant therapy, chelation therapy, and the use of synthetic antioxidants. These therapies have their own disadvantages, such as chelation with ethylenediaminetetraacetic acid (EDTA), which can lead to osteoporosis due to excretion of calcium from the body. Therefore, there is dire need to use some benign therapies such as ethnomedicines. Traditionally, ethnomedicines are being used extensively in the IndoPak region and elsewhere, mainly due to their costeffectiveness, easy accessibility, and perceived fewer side effects [10-11]. The mechanism of action of these herbal drugs is different in many respects from that of the synthetic drugs/pure compounds. This may be characterized as a polyvalent action and understood as an additive or potentiate.

In this study, a famous plant known as A. barbadensis Miller (Family Liliaceae) was selected (to deal with oxidative stress on the basis of its higher antioxidant activity) to prevent/reduce toxicity associated with cadmium. For this purpose we used the skin of mature aloe leaves. This plant is commonly used in folk medicine as it is antibacterial, antioxidant, antidiabetic, anticarcinogenic, hypocholesterolemic, hepatoprotective, and nephroprotective [12-17]. The polyphenolics and flavonoids reported so far in the aloe skin include sinapic acid, quercitrin, kaempferol, apigenin, catechin, quercetin, epicatechin, syringic acid, chlorogenic acid, gentisic acid, caffeic acid, ferulic acid, rutin, miricetin, and vanillic acid [18]. The possible protective activity of Aloe barbadensis aqueous extract against $\mathrm{Cd}$-induced renal and hepatotoxicity has not been reported so far. Therefore, in this study, Aloe barbadensis methanolic extract was sequentially partitioned to obtain different fractions, out of which an aqueous fraction termed as aloe aqueous fraction (AAF) was utilized to evaluate its protective effects against $\mathrm{Cd}$-induced sub-chronic oxidative kidney and liver injury models in male rabbits.

\section{Material and Methods}

\section{Collection, Identification, and Extraction of Plant Material}

Fresh leaves of Aloe barbadensis were collected from the Botanical Garden of the University of the Punjab, Lahore, during September-October. Identification and authentication were performed by the Department of Botany, GC University, Lahore. Fresh leaves were washed with distilled water, sliced into smaller pieces, air-dried, ground, and extracted with aqueous ethanol, $30: 70 \mathrm{v} / \mathrm{v}$ (plant material to solvent ratio, 1:20 w/v) using an ultrasonic bath for six hours at room temperature, then filtered through Wattman filter paper No. 1, and evaporated to dryness using a rotary evaporator (Edolph Rotary, Germany) according to Sytykiewicz et al. [19]. The residue was extracted three times for maximum yield. The crude extract, thus obtained, was suspended in doubledistilled water and successively partitioned with petroleum spirit and chloroform to get the respective fractions by using a rotary evaporator. The remaining aqueous fraction was lyophilized using Labconco, FreeZone 2.5, USA. Out of three fractions and crude extract, the aqueous fraction showed higher phenolic and flavonoid contents and the highest antioxidant potential. Thus the aqueous fraction was retained in a glass bottle, covered with aluminum foil, and kept in refrigerator until further use.

\section{In Vitro Determination of Total Phenolics, Flavonoids, and Antioxidant Contents}

The total phenolic contents of crude extract, petroleum spirit, chloroform, and aqueous fractions were determined as described by Liu et al., based on FolinCiocalteu's reagent method [20]. All the results were stated as mg gallic acid equivalents (GAE) per gram of sample. Total flavonoids were measured using the aluminum chloride method as described by Liu et al. [20]. Results of total flavonoid content were stated as mg catechin equivalents (CE) per gram of dry weight of sample. Total antioxidant capacity was determined using the phospho-molybdenum method by Prieto et al. [21], and stated as mg BHT equivalents (BHTE) per gram of sample. 


\section{Identification of Quercetin by RP-HPLC}

Aloe aqueous fraction (AAF) was prepared for HPLC identification by mixing a freeze-dried fraction $(100 \mathrm{mg})$ in $2 \mathrm{~mL}$ of methyl alcohol, uniformly homogenized by vortex at room temperature in darkness, and filtered through a $45 \mu \mathrm{m}$ nylon syringe filter prior to injection.

Chromatographic identification was performed on an LC-9 system equipped with a vacuum degasser, a thermostat column compartment, fixed loop injector $(20 \mu \mathrm{L})$, a binary pump, and UV-visible detector set at $373 \mathrm{~nm}$ - which all was connected to CSW32 software. The separation was performed with a reverse-phase C18 column. The mobile phases were water $(0.1 \%$ formic acid $)$ and acetonitrile, with flow rate of $0.6 \mathrm{~mL} / \mathrm{min}$.

\section{Animals}

In this study we used male albino rabbits (Oryctolagus cuniculus), aged 22-26 \pm 2 weeks, weighing 1.6-2.2 $\pm 0.1 \mathrm{~kg}$, bred in the Pakistan Council of Scientific and Industrial Research, Lahore-Pakistan animal house. The rabbits were fed on a routine rabbit diet and had free access to fresh drinking water. They were housed in individual cages and were handled under standard laboratory conditions of $12 \mathrm{~h}$ light:dark cycle at $24 \pm 3^{\circ} \mathrm{C}$ and relative humidity of $50 \pm 10 \%$. Before the commencement of the experiment all the rabbits were administered ivermectin $(0.1 \mathrm{~mL} / \mathrm{Kg}$ b.wt., s.c.) followed by a seven-day adjustment period. The study protocols were approved (18 June 2014) by the Advance Studies and Research Board (AS\&RB) of the University of the Punjab, Pakistan. Experimental protocols were in agreement with the National Institute of Health (NIH) guidelines for the care and use of laboratory animals [2]. Body weights were recorded every four days until the end of the experiment.

\section{Selection of Cadmium and AAF Dosage}

LD50 of cadmium (as cadmium chloride) was determined to be $61.34 \mathrm{mg} / \mathrm{Kg}$ b.wt. in male albino rabbits (data not shown). The $1 / 12^{\text {th }}$ dose of LD50 of cadmium (as cadmium chloride) was selected, i.e., $5.1 \mathrm{mg} / \mathrm{Kg}$ to induce toxicity in rabbits. To evaluate the appropriate dose of aloe aqueous fraction (AAF), three different concentrations (i.e., 50,100 , and $200 \mathrm{mg} / \mathrm{Kg}$ b.wt.) were administered orally for 10 days along with $\mathrm{CdCl}_{2}(5.1 \mathrm{mg} / \mathrm{Kg})$ daily. Various biochemical parameters like AST, ALT, ALP, $\mathrm{Cr}$, and Urea were estimated in serum (data not shown). Results of these parameters suggest that $200 \mathrm{mg} / \mathrm{Kg}$ b.wt./ day was found to be an appropriate dose to conduct this study.

\section{Experimental}

The experimental design has been constructed in accordance with that of Prabu et al. [1]. Rabbits were divided at random, into four groups (each containing six animals):
1. Control: non-treated animals received the vehicle only orally.

2. Received only an aqueous fraction of the leaf extract (AAF, $200 \mathrm{mg} / \mathrm{Kg} /$ day, orally).

3. Received cadmium in normal saline at a dose of $5.1 \mathrm{mg} / / \mathrm{Kg} /$ day orally.

4. Rabbits orally received $5.1 \mathrm{mg} / \mathrm{Kg} /$ day cadmium and $200 \mathrm{mg} / / \mathrm{Kg} /$ day aqueous extract.

This experimental study was conducted for 40 days, representing a sub-chronic model according to Bae et al. [22].

\section{Blood and Tissue Sampling}

Before commencement and after every $10^{\text {th }}$ day of the experiment, approximately $5 \mathrm{ml}$ of blood was collected from the marginal ear vein of each rabbit from all groups. Samples were divided into two aliquot: one of $2 \mathrm{ml}$ in EDTA containing a tube for CBC (data not shown), and the other of $3 \mathrm{ml}$ in a plain dry vacutainer to separate serum after centrifuging (1,000 rpm, $10 \mathrm{~min}$.) for biochemical analysis.

On day 40 dissection of all rabbits from each group was performed to remove liver and kidneys, which were rinsed with cold normal saline, dried, and weighed individually. Small portions of left kidneys and caudal parts of livers were preserved for histopathological examinations, and about one gram of each tissue was minced and homogenized (10 times the weight of tissue) in a buffer maintained at $\mathrm{pH} 7.4$ and cold centrifuged $(10,000 \mathrm{~g}$ for $10 \mathrm{~min}$ ). The resulting clear supernatant was collected for additional estimations.

\section{Estimating Serum Hepatic and Renal Marker Enzymes}

The activities of serum hepatic and renal markers like aspartate transaminase (AST), alanine transaminase (ALT), alkaline phosphatase (ALP), Gamma glutamyl transferase (GGT), urea, creatinine, albumin, total protein (TP), and total bilirubin (TB) were assayed using a chemistry analyzer (Microlab-300, Merck) according to the standardized procedures using diagnostic kits purchased from Merck (Pvt.) Ltd., Pakistan.

\section{Estimating Urine Renal Marker Enzymes}

Before commencement and after every $10^{\text {th }}$ day of experiment, the urine was collected on a $24 \mathrm{~h}$ basis using metabolic cages for each rabbit from all groups. Creatinine and urea levels were determined by spectrophotometric methods using commercial diagnostic kits.

\section{Determining Antioxidant Enzymes and Vitamins $\mathrm{C}$ and $\mathrm{E}$ in Tissues}

Superoxide dismutase (SOD) activity was measured in tissue homogenates using the method of Kakkar et al. 
[23] with a spectrophotometer at $560 \mathrm{~nm}$. Catalase activity (CAT; EC 1.11.1.6) was assayed in tissue homogenates by determining the rate of decomposition of $\mathrm{H}_{2} \mathrm{O}_{2}$ at $240 \mathrm{~nm}$ [24]. The levels of ascorbic acid (vitamin C) and alphatocopherol (vitamin E) were assayed in the kidney and liver homogenates according to the methods of Omaye et al. and Desai, respectively [25-26].

\section{Determining Cadmium Contents in Tissues}

The tissue samples of kidney and liver were oven-dried, weighed accurately, digested with nitric acid and hypochloric acid, and estimated by an atomic absorption spectrophotometer (Perkin Elmer Analyst 800). The calibration curve of cadmium was constructed using 01, 02, and 03 ppm standards (Perkin Elmer). Bovine liver (NIST:1577b) was used as standard/ certified reference material to ascertain the results of tested tissues.

\section{Histopathological Studies}

The left kidney and caudal part of liver tissue samples were fixed for 24 hours in buffered $10 \%$ formalin, washed under tapwater for 12 hours, then dehydrated by passing through different mixtures of ethanol and water, cleaned in xylene, and embedded in soft white paraffin. Rotary microtome was used to prepare tissue sections (5-6 mm thick) and stained with haematoxylin and eosin (H\&E) dye with neutral DPX medium for microscopic observations.

\section{Statistical Analysis}

All the data were expressed as mean values \pm standard deviation (S.D.) for six rabbits per group. The statistical significance was evaluated by one-way analysis of variance (ANOVA) using SPSS 16.0 version and the individual comparisons were obtained by Duncan's Multiple Range Test (DMRT). Values were considered statistically significant when $\mathrm{p}<0.05$.

\section{Results and Discussion}

\author{
Determination of Total Phenolics, Flavonoids, \\ and Antioxidant Contents
}

Antioxidant-rich compounds were extracted from leaf skin in aqueous methanol, and fractions of petroleum ether, chloroform, and water were obtained from sequential partitioning of crude extract. In this study, the amount of extraction yield (g/100 g of dry wt.), TPC (mg GAE/g of dry wt.), TFC (mg CE/g of dry wt.), and TAOC (mg BHTE/g of dry wt.) significantly varied between the various fractions of the leaf extracts and was dependent on the solvents used for fractionation. Yield, TPC, TFC, and TAOC of aqueous fraction were the highest, i.e., $13.7 \pm 2.6,98.5 \pm 4.8,46.2 \pm 2.1$, and $5.8 \pm 1.7$, respectively, and petroleum ether fraction showed the lowest values (Table 1). Our findings are in close agreement with Miladi and Sultana et al. [27-28]. The differences in TPC, TFC, and TAOC values may be attributed to the use of different solvents for extraction. It has been described in several studies that higher levels of phenolics may be associated with the use of more polar solvents for extraction [29]. Flavonoids and polyphenols are produced as natural secondary metabolites and possess rich antioxidant properties. The flavonoids are mainly comprised of six sub-classes that show some structural differences. These are capable of interacting and scavenging free radicals, which initially damage cells and result in various diseases. Our results clearly illustrate that phenolic and flavonoid compounds like quercetin (identified by HPLC in leaf skin as shown in Fig. 1) are most probably the major contributors to the observed higher antioxidant properties of the AAF.

\section{Changes in Body Weight of Rabbits}

Fig. 2 shows the variation in body weight among control, Cd-, Cd+AAF-, and AAF-treated rabbits during 40 days of study. Careful measurement of weight was performed on an electronic balance and was recorded after every four days until the end of the experiment. Cdreceiving group shows the decreasing trend in weight

Table 1. Percentage yields, total phenolics, flavonoids, and antioxidant capacity of Aloe barbadensis Miller leaf skin extract.

\begin{tabular}{|c|c|c|c|c|}
\hline Extract/Fraction & $\begin{array}{c}\text { Percentage yields } \\
(\mathrm{g} / 100 \mathrm{~g} \text { of DW) }\end{array}$ & $\begin{array}{c}\text { Total phenolics } \\
(\mathrm{mg} \mathrm{GAE} / \mathrm{g} \text { of DW })\end{array}$ & $\begin{array}{c}\text { Total flavonoids } \\
(\mathrm{mg} \text { CE/g of DW })\end{array}$ & $\begin{array}{c}\text { Total antioxidant capacity } \\
(\mathrm{mg} \text { BHTE/g of DW) }\end{array}$ \\
\hline Aqueous methanol & $9.8 \pm 1.9$ & $81.3 \pm 3.1$ & $32.5 \pm 1.8$ & $3.2 \pm 0.9$ \\
\hline Pet. Ether fraction & $21.4^{*} \pm 0.8$ & $11.3 \pm 1.9$ & $5.4 \pm 0.8$ & $1.1 \pm 0.5$ \\
\hline Chloroform fraction & $14.3^{*} \pm 0.5$ & $24.4 \pm 2.2$ & $9.1 \pm 1.1$ & $2.1 \pm 0.8$ \\
\hline Aqueous fraction & $64.2^{*} \pm 2.6$ & $98.5 \pm 4.8$ & $46.2 \pm 2.1$ & $5.8 \pm 1.7$ \\
\hline
\end{tabular}

*weight of fraction/weight of crude extract*100

Data are presented as means \pm standard deviation $(n=3)$; GAE: Gallic acid equivalents; CE: Catechin equivalents; BHTE: butylated hyhroxy toluene equivalents; DW: dry weight. 

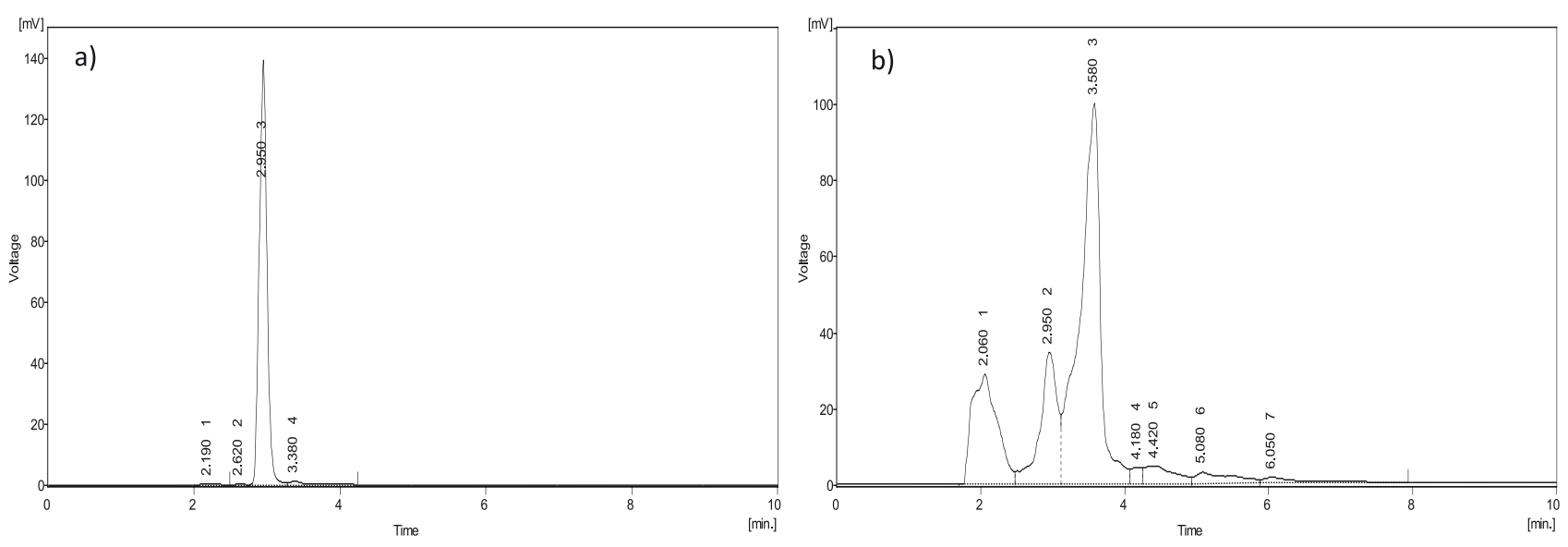

Fig. 1. a) Quercetin standard b) sample of aloe vera aqueous fraction (AAF).

gain from start to finish as compared to the control group as suggested by Sajjad et al. [30], whereas increases in weights of the cadmium-plus-AAF group was better when compared to only the Cd-receiving group. Values of only AAF-treated rabbits were in agreement with the control group and did not show significant variations in weights as shown in Fig. 2. The aloe aqueous fraction may have affected the overall health of animals due to the presence of polyphenols and flavonoids, or due to its high antioxidant activity, which may have resulted in counteracting the damage caused by $\mathrm{CdCl}_{2}$.

\section{Status of Serum Hepatic Marker Enzymes}

The aim of the present study was to evaluate the possible protective effects of Aloe aqueous fraction (AF) on hepatic toxicity due to oxidative stress induced by cadmium in male rabbits for 40 days. Table 2 shows the serum liver functional enzyme levels and the bilirubin of the control, cadmium, cadmium-plus-AAF, and the AAF

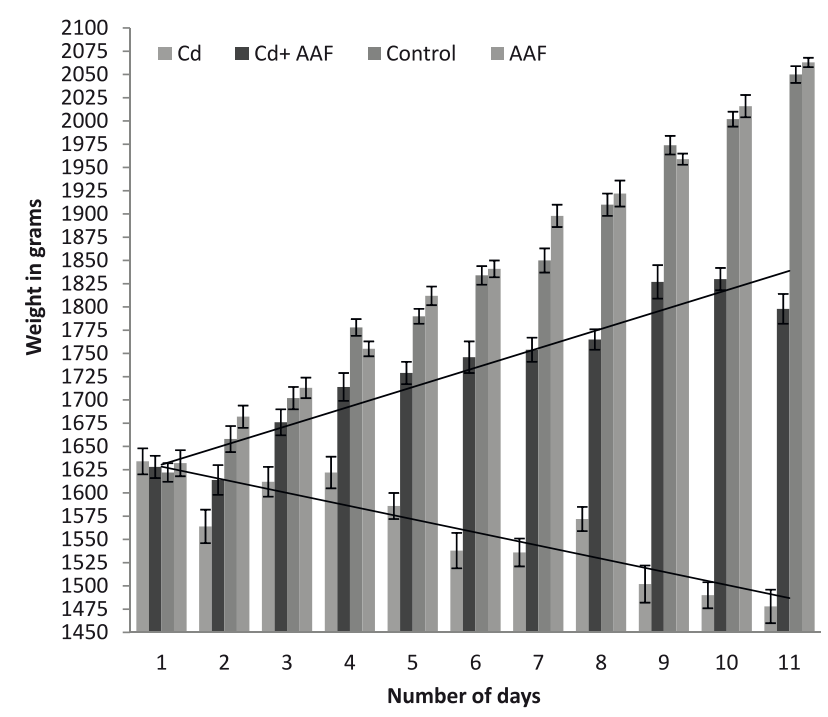

Fig. 2. Variation in body weights of male albino rabbits from the start and days 0-40 of the experiment (mean $\pm \mathrm{SD}, \mathrm{n}=6$ ). groups. Orally administered cadmium chloride may result in abnormal hepatic functions, in a progressive manner from day " 0 " to days $10,20,30$, and 40 of the experiment. The levels of serum enzymes such as transaminases (ALT, AST), alkaline phosphatase (ALP), gamma glutamyl transferase (GGT), and total bilirubin (TB) were gradually increased to show a significant incremental trend $(p<0.05)$ in cadmium-intoxicated rabbits when compared to the control group. Our findings are in close agreement with Renugadevi and Prabu et al. [31-32] regarding $\mathrm{Cd}$ intoxication significantly raising the serum total bilirubin and liver enzymes. Administering aqueous fraction of aloe (AAF, $200 \mathrm{mg} / \mathrm{kg} /$ day) plus Cd $(5.1 \mathrm{mg} / \mathrm{kg} /$ day $)$ significantly lowered $(p<0.05)$ the levels of liver enzymes and bilirubin when compared to the Cd-receiving group. Levels of liver functional enzymes and total bilirubin remained at satisfactory levels in the AAF group when compared to control rabbits as shown in Table 2.

The raised levels of liver enzymes may indicate leakage from the hepatic cells in the bloodstream and loss of hepatic histoarchitecture. Higher levels of transaminases and alkaline phosphatase are the deci sive factors for identifying liver injury in cadmiumintoxicated rabbits as described by Williamson et al. [33]. Serum GGT, an enzyme bound to membrane, is the most renowned indicator of cellular and tissue injury by lethal substances, and its level is also significantly increased in cadmium-intoxicated rabbits. In this study we raised levels of serum liver markers indicating that cadmium had caused functional and structural injury to the cellular membranes, and augmented membrane permeability, resulting in the leakage of liver enzymes into the blood stream. The serum level of bilirubin was also increased in cadmium-treated animals, suggesting that increased levels of serum bilirubin is a strong marker of liver dysfunction.

Hepatic damage can be protected either by strong antioxidant activity or by inhibiting the generation of free radicals [34]. Several results of various studies have also proved the protective effects of plants extracts on cadmium-induced hepatotoxicity [2, 35-36]. 
Table 2. Values of serum hepatic markers in male albino rabbits at the start, $10^{\text {th }}, 20^{\text {th }}, 30^{\text {th }}$ and $40^{\text {th }}$ day of experiment $(m e a n=S . D, n=6)$.

\begin{tabular}{|c|c|c|c|c|c|}
\hline \multirow{3}{*}{ Treatment } & \multicolumn{5}{|c|}{ Days } \\
\hline & 0 & 10 & 20 & 30 & 40 \\
\hline & \multicolumn{5}{|c|}{$\operatorname{ALT}(\mathrm{IU} / \mathrm{L})$} \\
\hline Cadmium & $53.0 \pm 4.0 \mathrm{aa}$ & $70 \pm 6.11 \mathrm{ab}$ & $95 \pm 6.06 \mathrm{ac}$ & $132 \pm 5.24 \mathrm{ad}$ & $188 \pm 8.35 \mathrm{ae}$ \\
\hline $\mathrm{Cd}+\mathrm{AAF}$ & $49 \pm 4.92 \mathrm{ba}$ & $61 \pm 7.4 b c$ & $76 \pm 6.79 \mathrm{bd}$ & $100 \pm 6.77 \mathrm{be}$ & $133 \pm 7.75 \mathrm{bf}$ \\
\hline AAF & $49 \pm 3.69 \mathrm{ba}$ & $52 \pm 4.9 \mathrm{ba}$ & $51 \pm 5.4 \mathrm{ba}$ & $55 \pm 4.6$ aа & $59 \pm 5.1 \mathrm{aa}$ \\
\hline Control & $54 \pm 4.5 \mathrm{aa}$ & $56.4 \pm 5.8 \mathrm{aa}$ & $60 \pm 4.1 \mathrm{aa}$ & $48 \pm 4.7 \mathrm{ba}$ & $59.1 \pm 3.5 \mathrm{aa}$ \\
\hline \multicolumn{6}{|c|}{ AST (IU/L) } \\
\hline Cadmium & $70 \pm 4.3 \mathrm{kl}$ & $90.0 \pm 5.3 \mathrm{hi}$ & $118.0 \pm 5.9 \mathrm{fg}$ & $157.0 \pm 7.2 \mathrm{~cd}$ & $215.0 \pm 6.1 \mathrm{a}$ \\
\hline $\mathrm{Cd}+\mathrm{AAF}$ & $71 \pm 5.6 \mathrm{kl}$ & $86 \pm 7.04 \mathrm{ij}$ & $107 \pm 9.13 \mathrm{gh}$ & $134 \pm 8.85 \mathrm{ef}$ & $173 \pm 8.95 \mathrm{c}$ \\
\hline AAF & $65 \pm 4.81$ & $71 \pm 4.9 \mathrm{kl}$ & $69 \pm 5.1 \mathrm{kl}$ & $62 \pm 5.401$ & $72 \pm 4.06 \mathrm{kl}$ \\
\hline Control & $69 \pm 5.4 \mathrm{kl}$ & $73 \pm 4.2 \mathrm{kl}$ & $76 \pm 5.3 \mathrm{kl}$ & $79 \pm 5.4 \mathrm{il}$ & $75 \pm 6.1 \mathrm{kl}$ \\
\hline \multicolumn{6}{|c|}{$\operatorname{ALP}(\mathrm{IU} / \mathrm{L})$} \\
\hline Cadmium & $126 \pm 3.25 \mathrm{cb}$ & $148.0 \pm 5.08 \mathrm{cc}$ & $177.0 \pm 4.81 \mathrm{~cd}$ & $216.0 \pm 6.63 \mathrm{ce}$ & $270.0 \pm 7.47 \mathrm{cf}$ \\
\hline $\mathrm{Cd}+\mathrm{AAF}$ & $121 \pm 3.02 \mathrm{da}$ & $136 \pm 5.55 \mathrm{db}$ & $156.5 \pm 6.28 \mathrm{dc}$ & $185.5 \pm 5.89 \mathrm{de}$ & $221 \pm 7.83 \mathrm{df}$ \\
\hline $\mathrm{AAF}$ & $123 \pm 3.2 \mathrm{da}$ & $120 \pm 4.8 \mathrm{da}$ & $131 \pm 3.35 \mathrm{db}$ & $122 \pm 4.72 \mathrm{da}$ & $128 \pm 3.60 \mathrm{cb}$ \\
\hline Control & $125 \pm 3.72 \mathrm{cb}$ & $122 \pm 2.54 \mathrm{da}$ & $128 \pm 2.79 \mathrm{cb}$ & $132 \pm 5.37 \mathrm{db}$ & $119 \pm 4.35 \mathrm{da}$ \\
\hline \multicolumn{6}{|c|}{ GGT (IU/L) } \\
\hline Cadmium & $2.10 \pm 0.28 \mathrm{ef}$ & $2.67 \pm 0.63 \mathrm{eg}$ & $3.68 \pm 1.07 \mathrm{eh}$ & $4.37 \pm 1.62 \mathrm{ei}$ & $5.75 \pm 1.02 \mathrm{ej}$ \\
\hline $\mathrm{Cd}+\mathrm{AAF}$ & $1.87 \pm 0.19 \mathrm{fa}$ & $2.2 \pm 0.40 \mathrm{fb}$ & $2.6 \pm 0.78 \mathrm{fc}$ & $3.3 \pm 1.14 \mathrm{fd}$ & $4.2 \pm 0.93 \mathrm{fe}$ \\
\hline AAF & $1.77 \pm 0.12 \mathrm{fa}$ & $1.9 \pm 0.14 \mathrm{fa}$ & $2.07 \pm 0.15 \mathrm{ef}$ & $1.83 \pm 0.12 \mathrm{fa}$ & $2.32 \pm 0.12 \mathrm{fb}$ \\
\hline Control & $2.05 \pm 0.19 \mathrm{ef}$ & $1.93 \pm 0.16 \mathrm{fa}$ & $2.12 \pm 0.12 \mathrm{ef}$ & $2.1 \pm 0.23 \mathrm{ef}$ & $1.81 \pm 0.22 \mathrm{fa}$ \\
\hline \multicolumn{6}{|c|}{ Total Bilirubin (mg/dL) } \\
\hline Cadmium & $0.21 \pm 0.02 \mathrm{gh}$ & $0.49 \pm 0.05 \mathrm{gi}$ & $0.68 \pm 0.07 \mathrm{gk}$ & $0.92 \pm 0.18 \mathrm{gl}$ & $1.43 \pm 0.27 \mathrm{gm}$ \\
\hline $\mathrm{Cd}+\mathrm{AAF}$ & $0.22 \pm 0.02 \mathrm{gh}$ & $0.41 \pm 0.04 \mathrm{gi}$ & $0.60 \pm 0.09 \mathrm{ic}$ & $0.84 \pm 0.11 \mathrm{id}$ & $1.09 \pm 0.31$ if \\
\hline AAF & $0.29 \pm 0.03 \mathrm{ia}$ & $0.33 \pm 0.02 \mathrm{ia}$ & $0.26 \pm 0.02 \mathrm{ia}$ & $0.31 \pm 0.03 \mathrm{ia}$ & $0.22 \pm 0.03 \mathrm{gh}$ \\
\hline Control & $0.20 \pm 0.02 \mathrm{gh}$ & $0.24 \pm 0.02 \mathrm{ia}$ & $0.31 \pm 0.03$ ia & $0.27 \pm 0.02 \mathrm{a}$ & $0.21 \pm 0.03 \mathrm{gh}$ \\
\hline
\end{tabular}

Means not sharing similar letter (for each parameter) in a row or in a column are statistically significant $(\mathrm{P}<0.05)$. Small letters represent comparison among interaction means of one parameter only.

\section{Status of Urine and Serum Renal Marker Enzymes and Serum Proteins}

Table 3 shows the urine and serum renal functional enzymes, serum albumin, and total proteins of control, cadmium, cadmium-plus-leaf extract, and leaf extract groups of adult male albino rabbits. Oral administration of cadmium chloride caused abnormal renal functions in a progressive manner from day " 0 " to days $10,20,30$, and 40 of the experiment. The levels of serum enzymes like creatinine and urea were gradually increased to show a significant incremental trend $(p<0.05)$ in cadmiumintoxicated rabbits when compared to the control group as described by Renugadevi et al. [31]. The administration of the aqueous fraction of aloe (AAF, $200 \mathrm{mg} / \mathrm{kg} /$ day) plus Cd (5.1 mg/kg/day) significantly decreased $(\mathrm{p}<0.05)$ these levels in serum when compared to only Cd-treated rabbits, while creatinine and urea levels were significantly decreased in urine samples in the Cd-group when compared to control as suggested by Mohamed and Thangapandiyan et al. [36-37]. The cadmium-plus-aqueous fraction of aloe resulted in significant improvement of these values when compared to the Cd group. Serum levels of albumin and total proteins were also decreased in the Cd group when compared to control - contrary to the results of Ige, who demonstrated an increase in serum albumin in cadmiumintoxicated rats. But our findings are in accordance with the results of Mohamed et al. [36, 38].

Cadmium plus aqueous extract significantly restored these levels when compared to only the Cd-treated group. Levels of urine and serum renal functional enzymes and serum albumin and total proteins remained at satisfactory 
Table 3. Values of creatinine, urea (in urine), albumin, creatinine, total proteins, and urea (serum) in male albino rabbits at the start and on days $10,20,30$, and 40 of the experiment (mean \pm S.D,$n=6$ ).

\begin{tabular}{|c|c|c|c|c|c|}
\hline \multirow{3}{*}{ Treatment } & \multicolumn{5}{|c|}{ Day } \\
\hline & Baseline & 10 & 20 & 30 & 40 \\
\hline & \multicolumn{5}{|c|}{ Urea in urine $(\mathrm{mg} / \mathrm{dL})$} \\
\hline Cadmium & $135 \pm 15 \mathrm{aa}$ & $115 \pm 18 \mathrm{ab}$ & $96 \pm 19 \mathrm{ac}$ & $82 \pm 16 \mathrm{ad}$ & $69 \pm 20 \mathrm{ae}$ \\
\hline $\mathrm{Cd}+\mathrm{AAF}$ & $133 \pm 18$ aa & $121 \pm 15$ ba & $111 \pm 18 b c$ & $94 \pm 19 \mathrm{bd}$ & $83 \pm 18$ be \\
\hline $\mathrm{AAF}$ & $138 \pm 17 \mathrm{aa}$ & $130 \pm 14 \mathrm{aa}$ & $135 \pm 17 \mathrm{aa}$ & $136 \pm 15 \mathrm{aa}$ & $132 \pm 18$ aa \\
\hline Control & $130 \pm 19 \mathrm{aa}$ & $133 \pm 17$ aa & $127 \pm 18 \mathrm{aa}$ & $136 \pm 19 \mathrm{aa}$ & $140 \pm 16$ aa \\
\hline \multicolumn{6}{|c|}{ Creatinine in urine $(\mathrm{mg} / \mathrm{dL})$} \\
\hline Cadmium & $2.9 \pm 0.3 \mathrm{ca}$ & $2.32 \pm 0.25 \mathrm{cb}$ & $1.91 \pm 0.3 \mathrm{~cd}$ & $1.55 \pm 0.2 \mathrm{ce}$ & $1.3 \pm 0.15 \mathrm{cf}$ \\
\hline $\mathrm{Cd}+\mathrm{AAF}$ & $2.8 \pm 0.4 \mathrm{ca}$ & $2.4 \pm 0.25 \mathrm{cb}$ & $2.15 \pm 0.3 \mathrm{da}$ & $1.9 \pm 0.15 \mathrm{db}$ & $1.7 \pm 0.2 \mathrm{bc}$ \\
\hline $\mathrm{AAF}$ & $2.4 \pm 0.25 \mathrm{cb}$ & $2.6 \pm 0.3 \mathrm{cb}$ & $2.5 \pm 0.4 \mathrm{cb}$ & $2.9 \pm 0.25 \mathrm{ca}$ & $2.8 \pm 0.3 \mathrm{ca}$ \\
\hline Control & $3.1 \pm 0.2 \mathrm{ca}$ & $2.9 \pm 0.25 \mathrm{ca}$ & $2.7 \pm 0.4 \mathrm{ca}$ & $3.2 \pm 0.35 \mathrm{ca}$ & $2.6 \pm 0.2 \mathrm{cb}$ \\
\hline \multicolumn{6}{|c|}{ Serum Albumin (mg/dL) } \\
\hline Cadmium & $3.90 \pm 0.5 \mathrm{ea}$ & $3.5 \pm 0.4 \mathrm{eb}$ & $2.9 \pm 0.5 \mathrm{ec}$ & $2.2 \pm 0.3 \mathrm{ed}$ & $1.8 \pm 0.4 \mathrm{ef}$ \\
\hline $\mathrm{Cd}+\mathrm{AAF}$ & $3.7 \pm 0.4 \mathrm{ea}$ & $3.4 \pm 0.5 \mathrm{ea}$ & $3.41 \pm 0.3 \mathrm{ea}$ & $2.72 \pm 0.5 \mathrm{ec}$ & $2.12 \pm 0.45 \mathrm{ed}$ \\
\hline $\mathrm{AAF}$ & $4.1 \pm 0.5 \mathrm{ea}$ & $3.6 \pm 0.4 \mathrm{ea}$ & $3.5 \pm 0.35 \mathrm{ea}$ & $3.9 \pm 0.5 \mathrm{ea}$ & $3.7 \pm 0.4 \mathrm{ea}$ \\
\hline Control & $3.4 \pm 0.6 \mathrm{ea}$ & $3.7 \pm 0.5 \mathrm{ea}$ & $3.6 \pm 0.3 \mathrm{ea}$ & $3.5 \pm 0.4 \mathrm{ea}$ & $3.9 \pm 0.5 \mathrm{ea}$ \\
\hline \multicolumn{6}{|c|}{ Serum Total proteins (mg/dL) } \\
\hline Cadmium & $7.50 \pm 0.7 \mathrm{fa}$ & $6.9 \pm 0.5 \mathrm{fb}$ & $6.1 \pm 0.4 \mathrm{fc}$ & $5.1 \pm 0.6 \mathrm{fd}$ & $3.9 \pm 0.5 \mathrm{fe}$ \\
\hline $\mathrm{Cd}+\mathrm{AAF}$ & $7.3 \pm 0.6 \mathrm{fa}$ & $7.1 \pm 0.4 \mathrm{fa}$ & $6.4 \pm 0.5 \mathrm{ga}$ & $5.8 \pm 0.35 \mathrm{gb}$ & $4.6 \pm 0.5 \mathrm{gc}$ \\
\hline $\mathrm{AAF}$ & $6.9 \pm 0.8 \mathrm{fb}$ & $7.1 \pm 0.5 \mathrm{fa}$ & $7.6 \pm 0.7 \mathrm{fa}$ & $7.1 \pm 0.6 \mathrm{fa}$ & $7.9 \pm 0.6 \mathrm{fa}$ \\
\hline Control & $7.2 \pm 0.5 \mathrm{fa}$ & $6.9 \pm 0.4 \mathrm{fb}$ & $7.4 \pm 0.5 \mathrm{fa}$ & $7.3 \pm 0.6 \mathrm{fa}$ & $7.8 \pm 0.4 \mathrm{fa}$ \\
\hline \multicolumn{6}{|c|}{ Serum Creatinine (mg/dL) } \\
\hline Cadmium & $1.6 \pm 0.26 \mathrm{ha}$ & $2.1 \pm 0.25 \mathrm{hb}$ & $2.7 \pm 0.3 \mathrm{hc}$ & $3.51 \pm 0.2 \mathrm{hd}$ & $4.62 \pm 0.3 \mathrm{he}$ \\
\hline $\mathrm{Cd}+\mathrm{AAF}$ & $1.5 \pm 0.15 \mathrm{ha}$ & $1.6 \pm 0.2 \mathrm{ha}$ & $1.8 \pm 0.15 \mathrm{ha}$ & $2.3 \pm 0.19 \mathrm{ia}$ & $2.8 \pm 0.1 \mathrm{hc}$ \\
\hline $\mathrm{AAF}$ & $1.8 \pm 0.3 \mathrm{ha}$ & $1.4 \pm 0.2 \mathrm{ha}$ & $1.3 \pm 0.1 \mathrm{ha}$ & $1.6 \pm 0.3 \mathrm{ha}$ & $1.5 \pm 0.2 \mathrm{ha}$ \\
\hline Control & $1.4 \pm 0.2 \mathrm{ha}$ & $1.3 \pm 0.15$ ha & $1.8 \pm 0.2 \mathrm{ha}$ & $1.5 \pm 0.1$ ha & $1.7 \pm 0.2 \mathrm{ha}$ \\
\hline \multicolumn{6}{|c|}{ Serum Urea (mg/dL) } \\
\hline Cadmium & $35 \pm 2.5 \mathrm{ja}$ & $45 \pm 3.6 \mathrm{jb}$ & $54 \pm 4.2 \mathrm{jc}$ & $69 \pm 3.8 \mathrm{jd}$ & $91 \pm 4.6 \mathrm{je}$ \\
\hline $\mathrm{Cd}+\mathrm{AAF}$ & $36 \pm 3.5 \mathrm{ja}$ & $43.5 \pm 2.8 \mathrm{jb}$ & $48.4 \pm 4.0 \mathrm{ka}$ & $59 \pm 4.5 \mathrm{~kb}$ & $73 \pm 3.9 \mathrm{kc}$ \\
\hline $\mathrm{AAF}$ & $38 \pm 3.8 \mathrm{ja}$ & $37 \pm 2.8 \mathrm{ja}$ & $31 \pm 3.2 \mathrm{ja}$ & $33 \pm 2.9 \mathrm{ja}$ & $39 \pm 3.6 \mathrm{ja}$ \\
\hline Control & $33 \pm 4.1 \mathrm{ja}$ & $34 \pm 3.5 \mathrm{ja}$ & $40 \pm 2.5 \mathrm{ja}$ & $37 \pm 3.8 \mathrm{ja}$ & $35 \pm 2.9 \mathrm{ja}$ \\
\hline
\end{tabular}

Means not sharing similar letter (for each parameter) in a row or in a column are statistically significant $(\mathrm{P}<0.05)$. Small letters represent comparison among interaction means of one parameter only.

levels only in the AAF-administered group when compared to control rabbits (Table 3). Prolonged exposure to cadmium may result in damage to various organs and systems, predominantly renal tissue [39]. Kidneys are more susceptible to injury because of greater perfusion and a large number of combinations are excreted by renal tubular cells. Urea is the major metabolic product obtained from protein metabolism that contains nitrogen.
It is well-documented that $\mathrm{Cd}$ hinders the incorporation of amino acids into proteins, leading to increased levels of urea. Creatinine is a waste product of creatine phosphate by muscle metabolism and it usually signifies impaired renal function or renal disease. As the kidneys become impaired, the creatinine level in serum will rise due to poor creatinine clearance by the kidneys. Thus the urea and creatinine levels in both serum and urine samples 
were considered indicators of renal functioning (because hyperuricemia is a renal prognostic factor). Administration of an antioxidant-rich fraction protects the renal function from cadmium-induced toxicity as shown by significantly restoring the serum and urine urea and creatinine. The present study supports the findings of Morales et al. [40]. Various results suggest that plant extracts may prevent nephrotoxicity by suppressing the oxidative stress caused by cadmium $[36,39,41-43]$.

\section{Determining Antioxidant Enzymes and Vitamins $\mathrm{C}$ and $\mathrm{E}$ in Tissues}

Table 4 shows the enzymatic anti-oxidants, i.e., superoxide dismutase and catalase and non-enzymatic antioxidants, vitamins $\mathrm{C}$ and $\mathrm{E}$ in liver and kidney homogenates of $\mathrm{Cd}, \mathrm{Cd}$-plus-AF, $\mathrm{AF}$, and control groups of adult male albino rabbits. Orally administered cadmium chloride caused abnormal renal and hepatic functions in a progressive manner from day " 0 " to 40 of the experiment, resulting in significantly decreased enzymatic and nonenzymatic antioxidants in liver and kidney samples in only the Cd-receiving group when compared to control. The cadmium-plus aqueous fraction of aloe resulted in significant improvement of these values when compared to the Cd group. Levels of these enzymatic (SOD, CAT) and non-enzymatic (vitamins $\mathrm{C}$ and $\mathrm{E}$ ) antioxidants in tissue homogenates remained at satisfactory levels only in the AAF-administered group when compared to control rabbits (Table 4 ).

Enzymatic antioxidants such as SOD and CAT may establish a supportive and defensive group against reactive oxygen species (ROS). Superoxide dismutase, being a metallo-protein, may catalyze the dismutation of superoxide radicals. Catalase, being a hemeprotein, may catalyze the reduction of $\mathrm{H}_{2} \mathrm{O}_{2}$ to $\mathrm{H}_{2} \mathrm{O}$ and $\mathrm{O}_{2}$, thus defending the cells from oxidative destruction by $\mathrm{H}_{2} \mathrm{O}_{2}$ and $\mathrm{OH}^{-}$. SOD activity may decrease either owing to the opposed effect of $\mathrm{Cd}$ with $\mathrm{Cu}$ and $\mathrm{Zn}$, which are considered significant metals due to their activity or inactivation of superoxide dismutase by lipid peroxidation induced by $\mathrm{Cd}$. It has been reported that the decline in CAT activity by $\mathrm{Cd}$ might reflect the reduced absorption of $\mathrm{Fe}$, a vital trace metal essential for the CAT activity [31]. Our results for this study are in accordance with Renugadevi and Waisberg et al. [44-45], who also showed that SOD and CAT activities are decreased by cadmium intoxication. The deficiency in the antioxidant defensive system may be considered an acute event in cadmium-induced hepatorenal toxicity. Cadmium exposure may be characterized by depletion of non-enzymatic antioxidants (vitamins $\mathrm{C}$ and E) in tissues and in the bloodstream. These are the main non-enzymatic antioxidants showing synergetic effects in scavenging reactive oxygen species or free radicals. Our findings are in accordance with Sk and Valko et al. [4647], who showed that the level of vitamin C (ascorbic acid) and vitamin $\mathrm{E}$ (alpha-tocopherol) are significantly reduced during $\mathrm{Cd}$ intoxication, leading to the development of $\mathrm{Cd}$ induced hepatic and renal impairment.

Administration of plant extracts in cadmiumintoxicated rabbits may protect the enzymatic and nonenzymatic antioxidants by means of either their metal chelation activity or by their antioxidant activities, which might reduce the exploitation of these antioxidants, thus reinstating their levels to near normal as described by Sakr et al. [48].

\section{Determining Cadmium Content in Tissues}

Table 4 also shows the cadmium contents in liver and kidneys of the $\mathrm{Cd}$, Cd-plus-AF, AF, and control groups of rabbits. Orally administered $\mathrm{CdCl}_{2}$ resulted in the accumulation of cadmium in renal and hepatic tissues, while a significant decrease in Cd contents was observed for the Cd-plus-aqueous fraction of the aloe group in liver and kidney samples when compared to the $\mathrm{Cd}$ group. Accumulation of cadmium in liver is a renowned result

Table 4. Catalase (CAT, $\mu \mathrm{mol} \mathrm{H}_{2} \mathrm{O}_{2} / \mathrm{min}$ ), Superoxide dismutase ( $\mathrm{SOD}$, units $/ \mathrm{mg}$ protein), ascorbic acid (Vitamin $\mathrm{C}, \mu \mathrm{mol} / \mathrm{mg}$ tissue) and alpha tocopherol (Vitamin E, $\mu \mathrm{mol} / \mathrm{mg}$ tissue) and cadmium content $(\mu \mathrm{g} / \mathrm{g})$ in liver and kidney of male albino rabbits on 40th day of experiment (mean \pm S.D, $n=6$ ).

\begin{tabular}{|c|c|c|c|c|c|}
\hline ORGANS & Parameters & Control & AAF & Cadmium & Cd + AAF \\
\hline \multirow{3}{*}{ KIDNEY } & CAT & $51.3 \pm 1.6^{\mathrm{a}}$ & $50.6 \pm 1.9^{\mathrm{a}}$ & $22.4 \pm 1.43^{\mathrm{b}}$ & $41.2 \pm 1.63^{\mathrm{c}}$ \\
\cline { 2 - 6 } & SOD & $11.71 \pm 0.78^{\mathrm{a}}$ & $11.14 \pm 0.81^{\mathrm{a}}$ & $5.32 \pm 0.52^{\mathrm{b}}$ & $8.97 \pm 0.63^{\mathrm{c}}$ \\
\cline { 2 - 6 } & Vitamin C & $0.95 \pm 0.07^{\mathrm{a}}$ & $0.93 \pm 0.09^{\mathrm{a}}$ & $0.48 \pm 0.04^{\mathrm{b}}$ & $0.69 \pm 0.05^{\mathrm{c}}$ \\
\cline { 2 - 6 } & Vitamin E & $0.62 \pm 0.05^{\mathrm{a}}$ & $0.61 \pm 0.0^{5} \mathrm{a}$ & $0.21 \pm 0.03^{\mathrm{b}}$ & $0.33 \pm 0.03^{\mathrm{c}}$ \\
\cline { 2 - 6 } & Cd content & $2.54 \pm 1.1^{\mathrm{a}}$ & $2.71 \pm 0.9^{\mathrm{a}}$ & $138.93 \pm 6.8^{\mathrm{b}}$ & $114.37 \pm 6.1^{\mathrm{c}}$ \\
\hline \multirow{3}{*}{ LIVER } & CAT & $68.4 \pm 1.9^{\mathrm{a}}$ & $70.1 \pm 2.1^{\mathrm{a}}$ & $27.8 \pm 1.5^{\mathrm{b}}$ & $50.36 \pm 1.7^{\mathrm{c}}$ \\
\cline { 2 - 6 } & SOD & $8.72 \pm 0.60^{\mathrm{a}}$ & $8.21 \pm 0.65^{\mathrm{a}}$ & $3.6 \pm 0.28^{\mathrm{b}}$ & $5.92 \pm 0.47^{\mathrm{c}}$ \\
\cline { 2 - 6 } & Vitamin C & $1.51 \pm 0.11^{\mathrm{a}}$ & $1.49 \pm 0.1^{\mathrm{a}}$ & $1.02 \pm 0.08^{\mathrm{b}}$ & $1.31 \pm 0.07^{\mathrm{c}}$ \\
\cline { 2 - 6 } & Vitamin E & $0.93 \pm 0.06^{\mathrm{a}}$ & $0.91 \pm 0.07^{\mathrm{a}}$ & $0.49 \pm 0.04^{\mathrm{b}}$ & $0.63 \pm 0.05^{\mathrm{c}}$ \\
\cline { 2 - 6 } & Cd content & $1.32 \pm 0.89^{\mathrm{a}}$ & $1.48 \pm 0.8^{\mathrm{a}}$ & $86.7 \pm 4.5^{\mathrm{b}}$ & $65.21 \pm 3.9^{\mathrm{c}}$ \\
\hline
\end{tabular}

a,b,c Values not sharing a common superscript letter $(a, b, c)$ in a row differ significantly at $p<0.05$. (Least Significant Difference) 
and it is recognized to produce hepatic oxidative injury by increasing per-oxidation of membraneous lipids - an injurious process exclusively performed by free radicals. Although free radicals are not generated by cadmium directly, numerous radicals like superoxide, nitric oxide, and hydroxyl are generated indirectly, thus producing injuries consistent with oxidative stress [49], whereas the
Cd-metallothionein (Cd-MT) complex formed in hepatic cells is released slowly by hepatic cells and circulates to the renal tissue. This Cd-MT complex is dissolved in renal cells, releasing free cadmium that is absorbed by proximal tubules. If renal metallothionein detoxification and defense systems are incredulous, free cadmium can cause injury to the renal proximal and distal tubules [50].
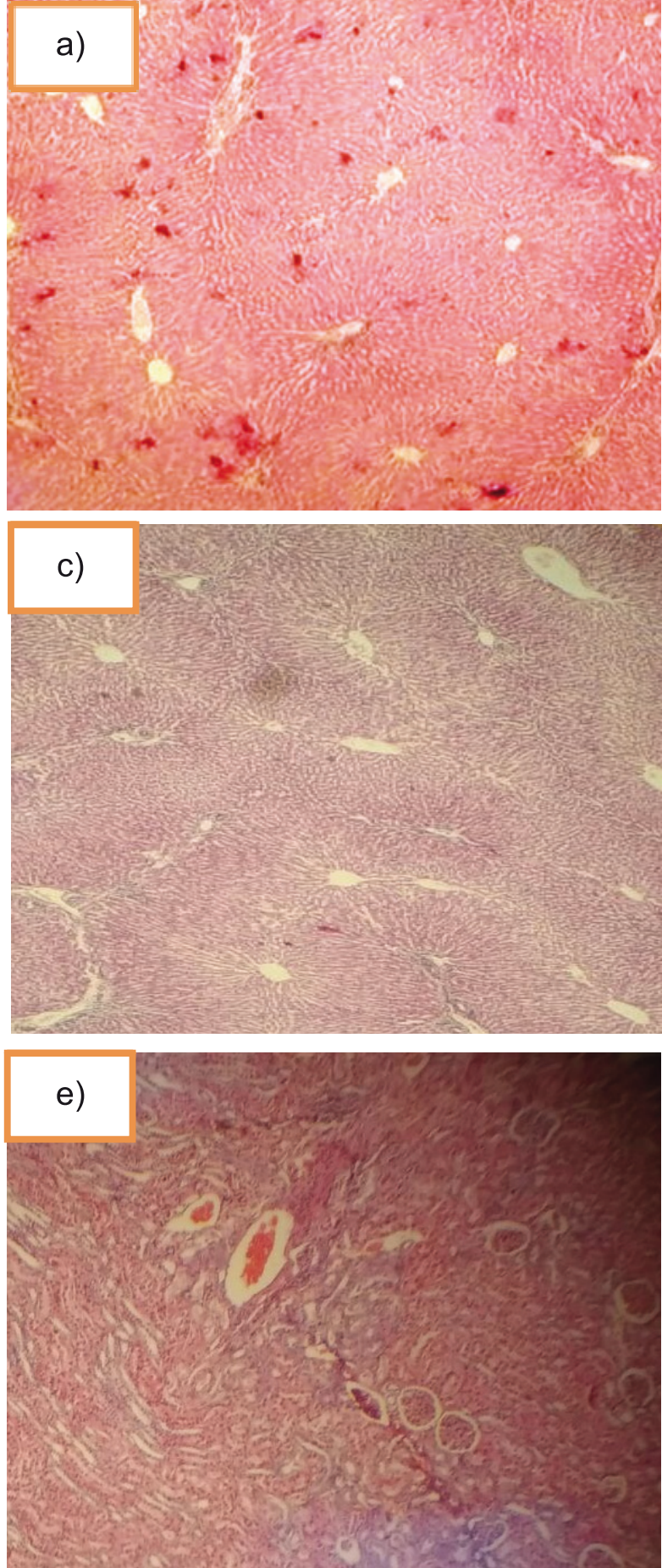
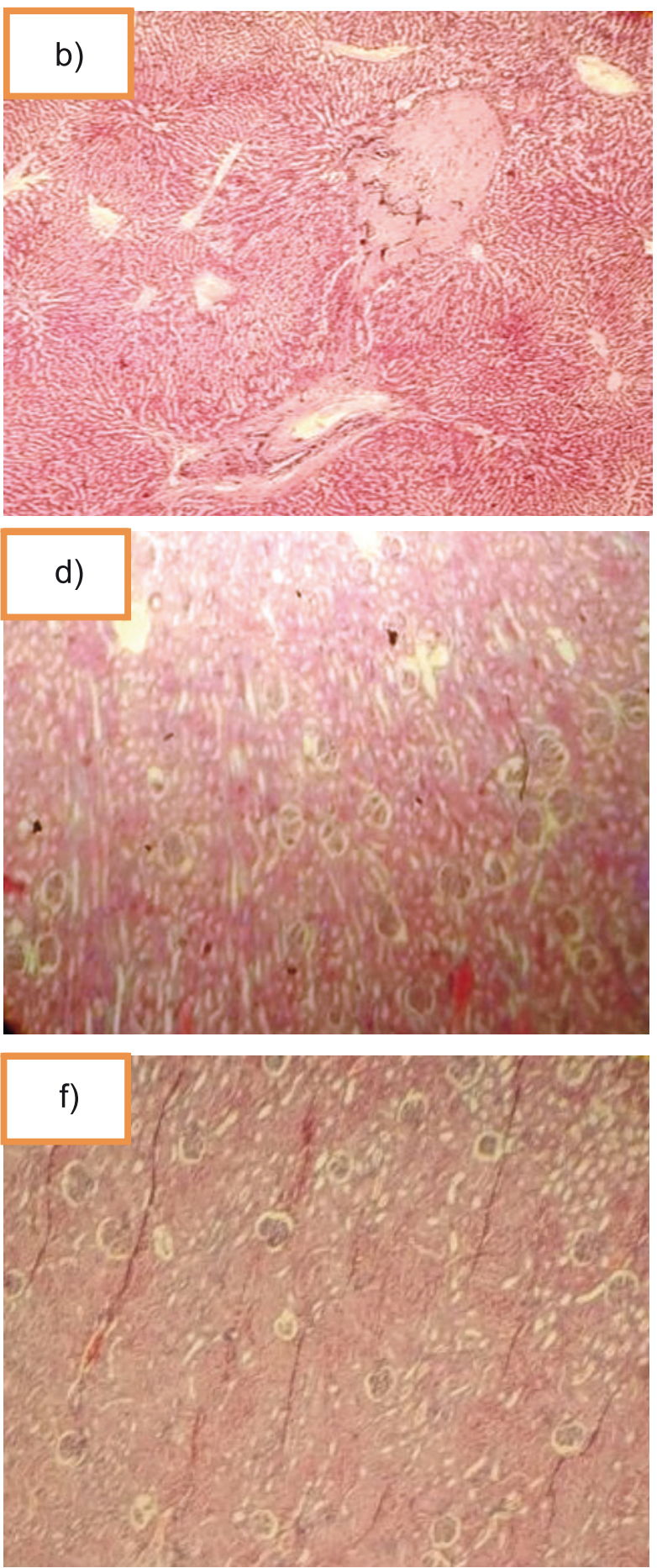

Fig. 3. Microphotograph of a) control group rabbit showing normal architecture of liver cells, b) $\mathrm{CdCl}_{2}$-intoxicated rabbit liver with periportal infiltrations and vascular congestion, c) $\mathrm{CdCl}_{2}$ - and AAF-treated rabbit liver with near-normal liver cells, d) control group rabbit showing normal architecture of renal cells, e) $\mathrm{CdCl}_{2}$-intoxicated rabbit kidney with swelling and glomerular congestion, and ( $\mathrm{F}$ ) $\mathrm{CdCl}_{2}-$ and AAF-treated rabbit with near normal renal cells. 


\section{Histopathological Studies}

Histopathological changes in the kidneys and liver were evaluated in such a manner that the histopathologist responsible for interpretation was kept unaware of the treatment protocols. Histopathological studies of liver of rabbits revealed that oral cadmium intoxication may have caused severe hepatic damage, including steatosis, sinusoidal dilation, inflammation of the central vein, inflammatory cell infiltration, portal inflammation, portal fibrosis, and necrosis when compared to control. These changes were reduced in livers of the AAF-plus-Cd treated group.

Histopathological studies of kidneys revealed that intoxication with orally administered $\mathrm{Cd}$ resulted in severe kidney damage, including proximal and distal tubular damage, hydropic swelling, and degeneration of tubular epithelium when compared to control. Significant reversal of these changes was observed in the AAF-plus-Cdtreated group. The histoarchitecture of liver and kidney was almost normal in rabbits treated with AAF alone (Fig. 3).

\section{Conclusion}

Significant decreases in biochemical hepatic and renal marker enzymes - in contrast to decreases in total bilirubin and albumin - were observed in a progressive manner in the $\mathrm{Cd}+\mathrm{AAF}$ group when compared to Cd-treated rabbits. Moreover, superoxide dismutase, catalase, and vitamins $\mathrm{C}$ and $\mathrm{E}$ in liver and kidney tissues were significantly increased, whereas cadmium content decreased for the $\mathrm{Cd}+\mathrm{AAF}$ rabbits as compared to the Cd-intoxicated rabbits. The histopathological studies for liver and kidney have also supported findings that the $\mathrm{Cd}+\mathrm{AAF}$ group noticeably lessened the toxicity of cadmium in both tissues at close to normal, thus suggesting that the flavonoid-rich fraction of AAF may act as a natural protective agent against $\mathrm{Cd}$ toxicity due to its high antioxidant activity.

\section{Acknowledgements}

The corresponding author of this manuscript acknowledges the role of Pakistan's Higher Education Commission for providing scholarship to undertake this study.

\section{References}

1. PRABU S.M., MUTHUMANI M., SHAGIRTHA K. Protective effect of Piper betle leaf extract against cadmiuminduced oxidative stress and hepatic dysfunction in rats. Saudi. J. Biol. Sci. 19 (2), 229, 2012.

2. NELKE K.H., MULAK M., LUCZAK K., PAWLAK W., NIENARTOWICZ J., SZUMNY D., KOCHMAN M., GERBER H. Occurrence and Exposure to Lead and Cadmium and Their Environmental Influence on Eyesight. Pol. J.
Environ. Stud. 24 (4), 1491, 2015.

3. ZANG Y., BOLGER P., Toxic Metals: cadmium. Encycl. Food Saf. 2, 346, 2014.

4. OLA H., MONEIM A.E.A. Testing the genotoxicity, cytotoxicity, and oxidative stress of cadmium and nickel and their additive effect in male mice. Biol. Trace Elem. Res. 159, 364, 2014.

5. GE W., JIAO Y., ZOU J., JIANG W., LIU D. Ultrastructural and Photosynthetic Response of Populus 107 Leaves to Cadmium Stress. Pol. J. Environ. Stud .24 (2), 519, 2015.

6. BHARAVI K., REDDY A.G., RAO G.S., REDDY A.R., RAO S.R. Reversal of cadmium-induced oxidative stress in chicken by herbal adaptogens Withania somnifera and Ocimum sanctum. Toxicol. Int. 17 (2), 59, 2010.

7. NINKOV M., ALEKSANDROV A.P., DEMENESKU J., MIRKOV I., MILEUSNIC D., PETROVIC A., GRIGOROV I., ZOLOTAREVSKI L., TOLINACKI M., KATARANOVSKI D., BRCESKI I., KATARANOVSKI, M. Toxicity of oral cadmium intake: Impact on gut immunity. Toxicol. Lett. 237 (2), 89, 2015.

8. DEMENESKU J., MIRKOV I., NINKOV M., ALEKSANDROV A.P., ZOLOTAREVSKI L., KATARANOVSKI D., KATARANOVSKI M. Acute cadmium administration to rats exerts both immunosuppressive and proinflammatory effects in spleen. Toxicology. 326, 96, 2014.

9. AGNIHOTRI S.K., AGRAWAL U., GHOSH I. Brain most susceptible to cadmium induced oxidative stress in mice. J. Trace Elem. Med. Biol. 30, 184, 2015.

10. RATHEE J.S., PATRO B.S., MULA S., GAMRE S., CHATTOPADHYAY S. Antioxidant activity of Piper betel leaf extract and its constituents. J. Agr. Food Chem. 54 (24), 9046, 2006.

11. AL-OLAYAN E., EL-KHADRAGY M., METWALLY D., ABDEL MONEIM A. Protective effects of pomegranate (Punica granatum) juice on testes against carbon tetrachloride intoxication in rats. BMC Complement. Altern. Med.14, $164,2014$.

12. MOHAMED E.A.K. Antidiabetic, antihypercholestermic and antioxidative effect of Aloe vera gel extract in alloxan induced diabetic rats. Aust. J. Basic Appl. Sci. 5 (11), 1321, 2011.

13. EZURUIKE U.F., PRIETO J.M. The use of plants in the traditional management of diabetes in Nigeria: Pharmacological and toxicological considerations. J. Ethnopharmacol. 155 (2), 857, 2014.

14. CUI Y., YE Q., WANG H., LI Y., YAO W., QIAN H. Hepatoprotective potential of Aloe vera polysaccharides against chronic alcohol-induced hepatotoxicity in mice. J. Sci. Food Agr. 94 (9), 1764, 2014.

15. EL-SHEMY H.A., ABOUL-SOUD M.A.M., NASSRALLAH A.A., ABOUL-ENEIN K.M., KABASH A., YAGI A. Antitumor properties and modulation of antioxidant enzymes' activity by Aloe vera leaf active principles isolated via supercritical carbon dioxide extraction. Curr. Med. Chem. 17 (2), 129, 2010.

16. CHANDAN B.K., SAXENA A.K., SHUKLA S., SHARMA N., GUPTA D.K., SURI K.A., SINGH B. Hepatoprotective potential of Aloe barbadensis Mill. against carbon tetrachloride induced hepatotoxicity. J. Ethnopharmacol. 111 (3), 560, 2007.

17. BARADARAN A., NASRI H., NEMATBAKHSH M., RAFIEIAN-KOPAEI M. Antioxidant activity and preventive effect of aqueous leaf extract of Aloe Vera on gentamicininduced nephrotoxicity in male wistar rats. Clin. Ter. 165 (1), 7, 2013 
18. LÓPEZ A., DE TANGIL M.S., VEGA-ORELLANA O., RAMÍREZA.S., RICO M. Phenolic constituents, antioxidant and preliminary antimycoplasmic activities of leaf skin and flowers of Aloe vera (L.) Burm. f. (syn. A. barbadensis Mill.) from the Canary Islands (Spain). Molecules. 18 (5), 4942, 2013.

19. SYTYKIEWICZ H., CHRZANOWSKI G., CZERNIEWICZ P., LESZCZYŃSKI B., SPRAWKA I., KRZYŻANOWSKI R., MATOK H. Antifungal Activity of Juglans regia (L.) Leaf Extracts Against Candida albicans Isolates. Pol. J. Environ. Stud. 24 (3), 1339, 2015.

20. LIU X., ZHAO M., WANG J., YANG B., JIANG Y. Antioxidant activity of methanolic extract of emblica fruit (Phyllanthus emblica L.) from six regions in China. J. Food Compost. Anal. 21, 219, 2008.

21. PRIETO P., PINEDA M., AGUILAR M. Spectrophotometric quantitation of antioxidant capacity through the formation of a phosphomolybdenum complex: specific application to the determination of vitamin E. Analyt. Bio. Chem. 269, 337, 1999.

22. BAE J.W., KIM D.H., LEE W.W., KIM H.Y., SON C.G. Characterizing the human equivalent dose of herbal medicines in animal toxicity studies. J. Ethnopharmacol. 162, 1, 2015.

23. KAKKAR P., DAS B., VISWANATHAN P.N. A modified spectrophotometric assay of superoxide dismutase. Indian J. Biochem. Biophys. 21, 130, 1984.

24. AEBI H. CATALASE. in: BERG MEYER H. (Ed.), Methods of Enzymatic Analysis, second ed. Verlag chemie, Weinheim, Germany, 673, 1974.

25. OMAYE S.T., TURNBULL J.D., Sauberlich H.E. Selected methods for the determination of ascorbic acid in animal cells, tissues and fluids. Method Enzymol. 62, 3, 1979.

26. DESAI I.D. Vitamin E analysis method for animal tissues. Method Enzymol.105, 138, 1984.

27. MILADI S., DAMAK M. In vitro antioxidant activities of Aloe vera leaf skin extracts. J. Soc. Chim. Tunis. 10, 101, 2008.

28. SULTANA B., ANWAR F., ASHRAF M. Effect of extraction solvent/technique on the antioxidant activity of selected medicinal plant extracts. Molecules. 14 (6), 2167, 2009.

29. LÓPEZ A., RICO M., RIVERO A., SUAREZ DE TANGIL M. The effects of solvents on the phenolic contents and antioxidant activity of Stypocaulon scoparium algae extracts. Food Chem. 125, 1104, 2011

30. SAJJAD S., MALIK H., FAROOQ U., RASHID F., NASIM H., TARIQ S., REHMAN, S. Cadmium chloride toxicity revisited: effect on certain andrological, endocrinological and biochemical parameters of adult male rabbits. Physiol. Res. 63, 505, 2014.

31. RENUGADEVI J., PRABU S.M. Cadmium-induced hepatotoxicity in rats and the protective effect of naringenin. Exp. Toxicol. Pathol. 62 (2), 171, 2010.

32. PRABU M.S., SELVARAJAN N., HEMALATHA S., RAMESHKUMAR T. Hepatoprotective effect of Andrographis paniculata against cadmium induced toxicity in male Wistar rats. Toxicol. Inter. 15 (1), 21, 2008.

33. WILLIAMSON E.M., OKPAKO D.T., EVANS F.J. Pharmacological methods in phytotherapy research, John Wiley \& Sons. 1, 1996.

34. SHAHJAHAN M., SABITHA K.E., JAINU M., SHYAMALA C.S. Effect of Solanum trilobatum against carbon tetrachloride induced hepatic damage in albino rats. Indian J. Med. Res. 120, 194, 2004.
35. BORDE A.U., QURESHI M.I., PATIL M.K., MENDHE M.S., ATHAWALE A.M. Protective effect of Withania Somnifera on cadmium chloride induced hematological and biochemical changes in male rats. J. Res. Educ. Indian Med. 15 (2), 15, 2008.

36. MOHAMED M.M., MOHAMED A.H. Protective role of garlic against cadmium toxicity in rats: Clinicopathological and histopathological studies. Egypt. J. Comp. Path. \& Clinic. Path. 22 (3), 2009.

37. THANGAPANDIYAN S., SUMEDHA N.C., MILTONPRABU S. Mentha piperita protects against Cadmium induced oxidative renal damage by restoring antioxidant enzyme activities and suppressing inflammation in rats. Inter. J. Pharmacol. Toxicol. 1 (2), 17, 2013.

38. IGE S.F., AKHIGBE R.E. Common onion (Allium cepa) extract reverses cadmium induced organ toxicity and dyslipidaemia via redox alteration in rats. Pathophysiology. 20 (4), 269, 2013.

39. JIN T., NORDBERG M., FRECH W., DUMONT X., BERNARD A., YE T.T., KONG Q., WANG Z., LI P., LUNDSTRÖM N., LI Y., NORDBERG G.F. Cadmium biomonitoring and renal dysfunction among a population environmentally exposed to cadmium from smelting in China. Biometals. 15 (4), 397, 2002.

40. MORALES A.I., VICENTE-SANCHEZ C., EGIDO J., AREVALO M.A., LOPEZNOVOA J.M. Protective effect of quercetin on experimental chronic cadmium nephrotoxicity in rats is based on its antioxidant properties. Food Chem. Toxicol. 44, 2092, 2006a.

41. SURU S.M. Onion and garlic extracts lessen cadmiuminduced nephrotoxicity in rats. Biometals. 21 (6), 623, 2008.

42. SHATI A.A. Effects of Origanum majorana L. on cadmium induced hepatotoxicity and nephrotoxicity in albino rats. Saudi Med. J. 32 (8), 797, 2011.

43. OJO O.A., AJIBOYE B.O., OYINLOYE B.E., OJO A.B., OLAREWAJU O.I. Protective effect of Irvingia gabonensis stem bark extract on cadmium induced nephrotoxicity in rats. Interdiscip. Toxicol. 7 (4), $208,2014$.

44. RENUGADEVI J., PRABU S.M. Quercetin protects against oxidative stress-related renal dysfunction by cadmium in rats. Exp. Toxicol. Pathol. 62 (5), 471, 2010.

45. WAISBERG M., JOSEPH P., HALE B., BEYERSMANN D. Molecular mechanisms of cadmium carcinogenesis. Toxicology. 192, 95, 2003.

46. SK U.H., BHATTACHARYA S. Prevention of cadmium induced lipid peroxidation, depletion of some antioxidative enzymes and glutathione by a series of novel organoselenocyanates. Environ. Toxicol. Pharmacol. 22 (3), 298, 2006.

47. VALKO M., MORRIS H., CRONIN M.T.D. Metals toxicity and oxidative stress. Curr. Med. Chem. 12, 1161, 2005.

48. SAKR S.A., BAYOMY M.F., EL-MORSY A.M. Rosemary extract ameliorates cadmium-induced histological changes and oxidative damage in the liver of albino rat. J. Basic Applied Zoology. 71, 1, 2015.

49. STOHS S.J., BAGCHI D., HASSOUN E., BAGCHI M. Oxidative mechanisms in the toxicity of chromium and cadmium ions. J. Environ. Pathol. Toxicol. Oncol. 20, 77, 2000.

50. PATRICK L. Toxic metals and antioxidants: part II. The role of antioxidants in arsenic and cadmium toxicity. Altern. Med. Rev. 8, 106, 2003. 